\title{
Abstracts/Résumés
}

\section{Les formes nominales $[\mathrm{CiCC}]$ et $[\mathrm{CCiC}]$ en arabe marocain ou la persistance des schèmes}

Abdeljebbar Amimi et Georges Bohas, Université de Paris 8

\begin{abstract}
This article deals with a vexing problem in the phonology of Moroccan Arabic, the alternation between $[\mathrm{CiCC}]$ and $[\mathrm{CCiC}]$ nouns. It is shown that this alternation cannot be predicted in all instances from the phonetic nature of the consonants, contrary to what has been claimed in previous analyses, and that it is necessary to have recourse to an analysis based on the notion of templates. It is claimed that the difference between the two forms $[\mathrm{CiCC}]$ and $[\mathrm{CCiC}]$ reflects an underlying difference between the three templates / $\mathrm{CVCC} / \mathrm{CVCVC} /$, and /(?a)CCVC/, which are shared by both Classical Arabic and Moroccan Arabic. The influence of sonority is secondary and only accounts for the appearance of $[\mathrm{CCiC}]$ forms in nouns derived from the template /CVCC/ whose last consonant is a nasal ( [jbin] 'cheese), a liquid ( [bћir] 'sea'), or a / / / ( [zric] 'wheat').
\end{abstract}

\section{Résumé}

Cet article aborde une question qui a fait l'objet de nombreuses études dans les quinze dernières années : l'alternance $[\mathrm{CiCC}] /[\mathrm{CCiC}]$ dans les noms nominales en arabe marocain. Il est démontré que ces études, qui se fondent sur les propriétés phonétiques des deux dernières consonnes, sont mises en échec par de nombreuses données et que seule une analyse basée sur la notion de schèmes permet de rendre compte de la majorité des formes. Il est proposé que la différence entre les deux formes $[\mathrm{CiCC}]$ et $[\mathrm{CCiC}]$ reflète une différence sous-jacente entre les trois schèmes $/ \mathrm{CVCC} /, / \mathrm{CVCVC} /$ et $/(\mathrm{Pa}) \mathrm{CCVC} /$ qui sont communs à l'arabe classique et à l' arabe marocain. L'intervention de la sonorité explique seulement l'apparition de formes $[\mathrm{CCiC}]$ dans des noms de schème $/ \mathrm{CVCC} /$ dont la dernière consonne est une nasale ( [jbin] 'fromage'), une liquide ( [bћir] 'mer') ou un /q/ ( [zrii] 'blé'). 


\title{
Nominal Infinitives in Spanish: An Aspectual Constraint
}

\author{
Elena de Miguel, Universidad Autónoma de Madrid
}

\begin{abstract}
The aim of this article is to provide an analysis of two types of Spanish infinitival constructions headed by a determiner. In an attempt to define the categorial status of the infinitive morpheme, it is proposed that there are two homophonous infinitival morphemes which project two different structures: one of them is inflectional in nature and projects clausal configurations; the other one is derivational in nature and projects nominal structures. This latter suffix carries an activity aspect and attaches only to aspectually compatible verbal stems. This proposal explains the different properties and contexts for the two structures analysed, and, more interestingly, provides an account for a number of data that remained unexplained in previous analyses.
\end{abstract}

\section{Résumé}

Le but de cet article est de présenter une analyse de deux types de constructions infinitives introduites par un déterminant en espagnol. L'examen du statut catégoriel du morphème d'infinitif conduit à l'hypothèse qu'il existe deux morphèmes homophones d'infinitif projetant deux structures différentes. L'un, de nature flexionnelle, projette des configurations phrastiques; l'autre, de nature dérivationnelle, projette des structures nominales. Ce dernier suffixe comporte une information aspectuelle d'activité et ne peut être affixé qu'à des bases verbales aspectuellement compatibles. Cette hypothèse permet d'expliquer la diversité des propriétés et des contextes des structures en question et rend compte notamment d'un certain nombre de faits encore non expliqués. 